\title{
Ku uczczeniu pamięci Kazimierza Twardowskiego
}

DOI: http://dx.doi.org/10.12775/RF.2018.005

\section{We Lwowie}

Staraniem Senatu Akademickiego i Rady Wydziału Humanistycznego Uniwersytetu Jana Kazimierza oraz Polskiego Towarzystwa Filozoficznego we Lwowie odbyła się dnia 30. kwietnia 1938 o godz. 17.30 w Auli Uniwersytetu Jana Kazimierza uroczysta Akademia Żałobna ku czci Kazimierza Twardowskiego.

Na program Akademii złożyły się:

1. Marsz żałobny z III Symfonii L. v. Beethovena w wykonaniu orkiestry Filharmonii lwowskiej pod batutą Adama Sołtysa, Dyrektora Polskiego Towarzystwa Muzycznego we Lwowie.

2. Zagajenie Prof. Dra R. Longchamps'a, Prorektora Uniwersytetu Jana Kazimierza.

3. Przemówienia:

Dra Tadeusza Czeżowskiego, Profesora Uniwersytetu Stefana Batorego,

Dra Romana Ingardena, Profesora Uniwersytetu Jana Kazimierza, Dra Stanisława Łempickiego, Profesora Uniwersytetu Jana Kazimierza.

4. Dwie pieśni Kazimierza Twardowskiego: 1. Do słów Fr. Nietzsche'go („,O Mensch, gib Acht...") i 2. Do słów St. Brzozowskiego (,O przyjdź, jesienią...“) w wykonaniu Mry Marii Jędrzejewskiej przy akompaniamencie H. Mieniewskiej-Rzepeckiej.

Na Akademii reprezentowali: Prof. Fr. Bujak Polską Akademią Umiejętności, Prof. Dr A. Łomnicki Warszawskie Towarzystwo Naukowe, Prof. Dr J. Hirschler Towarzystwo Naukowe we Lwowie, Prorektor Ciechanowski Politechnikę Lwowska, Rektor Szczudłowski Akademię Medycyny Weterynaryjnej we Lwowie, Płk. Fiałkowski D. O. K., Płk. 
Liebich Legię Akademicka, Wiceprezydent Irzyk miasto Lwów. Pisma i telegramy nadesłali: Polska Akademia Umiejętności, Warszawskie Towarzystwo Naukowe, Poznańskie Towarzystwo Przyjaciół Nauk, Komitet Kasy im. Mianowskiego, Poznańskie Towarzystwo Filozoficzne, Wileńskie Towarzystwo Filozoficzne, Towarzystwo Psychologiczne im. J. Joteyko. Nadto: L. Pomian-Biesiekierski, Stefan Błachowski, Bronisław Dembiński, Jan Łukasiewicz, Ks. Konstanty Michalski, Michał Sobeski, Władysław Szumowski.

Wszystkie przemówienia, wygłoszone na Akademii, zostaną ogłoszone drukiem w osobnej publikacji, która ukaże się staraniem Polskiego Towarzystwa Filozoficznego we Lwowie.

Tok myśli tych przemówień podajemy poniżej.

Prof. T. Czeżowski, charakteryzując działalność nauczycielską Kazimierza Twardowskiego, przypomniał, że gdy Twardowski objął w r. 1895 katedrę filozofii w Uniwersytecie lwowskim, filozofia polska rozwijała się w niezwiązanych z sobą ogniskach, które zaszczepiały na nasz grunt zaczerpnięte przeważnie z zewnątrz idee. Brakowało wewnętrznej ciągłości w rozwoju badań filozoficznych, bo nie było własnej szkoły filozoficznej. Taką szkołę stworzył Twardowski. Z chwilą odzyskania niepodległości nie tylko opanowała ona nowo powstałe placówki pracy filozoficznej w Polsce, lecz nadto wpływem swym objęła także niezwiązanych z nią bezpośrednio pracowników filozoficznych, wytwarzając pewien jednolity styl pracy badawczej. Uczniowie Twardowskiego, działając od lat dwudziestu kilku na katedrach uniwersyteckich, wykształcili z kolei nowe pokolenie badaczy, z których wielu krzewi już $\mathrm{z}$ katedry myśl filozoficzną wszczepioną $\mathrm{w}$ umysły ich nauczycieli przez Twardowskiego. Tak z jedności pracy filozoficznej wyłoniła się jedność filozofii polskiej, posiadającej własne wyraźne oblicze, znanej i uznanej na terenie międzynarodowym. Oto dzieło Twardowskiego jako nauczyciela.

W Jego twórczej działalności nauczycielskiej, która dzieło to wydała, wyróżnić należy trzy składniki: ideał wykształcenia filozoficznego, metodę nauczania i jej realizację. Na ideał filozofa składają się momenty zarówno intelektualne, jak i moralne, siła myśli, zarówno jak i siła charakteru, połączenie zrealizowane w osobach mędrców starożytności. Metoda nauczania jako środek osiągnięcia tego rodzaju dążeń pedagogicznych i dydaktycznych jest dobrze wszystkim znana i powszechnie dziś w Polsce stosowana, czasem bez świadomości, że pochodzi od Twardowskiego. Uzupełnia ona pracę programowa, najskrupulatniej wykonywana, innymi formami obcowania intelektualnego, sięgającymi daleko poza ławę uniwersytecką. Najważniejszym momentem tej metody był wzór, jaki Twardowski dawał własnym życiem i własną twórczościa, jako znakomitym i sugestywnie działającym przykładem spełnienia celów, wskazywanych uczniom. Taki sposób realizacji metody naucza- 
nia podaje rozwiązanie podstawowego zagadnienia wszelkiej pedagogiki, mianowicie należytego ustosunkowania nauczania i wychowania. Twardowski wychowywał przez nauczanie. Wychowywał tzn. kształcił charaktery, wyrabiając w swych uczniach zasady etyczne - wiarę w istnienie wartości bezwzględnych prawdy i dobra jako celów bezinteresownego dążenia - i dyspozycje woli: obowiązkowość, sumienność, dokładność.

W swym przemówieniu „O dostojeństwie Uniwersytetu” zamknął Twardowski swój testament nauczycielski, stwierdzający, że swe powołanie nauczycielskie nade wszystko cenił. Kiedyś indziej mówił o szczęściu, jakiego doznaje $\mathrm{w}$ nagrodę za swą działalność nauczycielską. Te ludzkie uczucia uzupełniają nam Jego postać - postać Człowieka i Nauczyciela w najpiękniejszym tego słowa znaczeniu.

Prof. R. Ingarden przedstawił działalność naukową Kazimierza Twardowskiego, poświęcając główną część swego przemówienia analizie poglądów zawartych w rozprawie „Zur Lehre vom Inhalt und Gegenstand der Vorstellungen" tudzież roli jej w rozwoju różnych odłamów szkoły austriackiej. Rozróżnienie między aktem, treścią i przedmiotem przedstawienia, samo zależne od poglądów Kerry'ego, wprowadziło pewne istotne korektury w poglądy Brentany i niektórych jego uczniów oraz dało impuls do dalszych opisowych analiz podstawowych struktur świadomości. Zrąb ogólnej teorii przedmiotu, bliski w zasadniczej koncepcji przedmiotu niektórym twierdzeniom J. Locke'a, wyprzedził Husserla „naukę o całościach i częściach” zawartą w II. T. „Logische Untersuchungen“, jako też $t z w$. Gegenstandstheorie Meinonga i nie pozostał również bez wpływu na nie, jakkolwiek autorowie ci szukali na ogół odmiennych, niż Twardowski, rozwiązań. Także niektóre badania Leśniewskiego i reizm Kotarbińskiego stanowią pewnego rodzaju reakcję na podstawową koncepcję przedmiotu u Twardowskiego. Obrona „przedmiotów ogólnych" przeciwstawia się dość wyraźnie ówczesnym prądom empirystycznym i stanowi niejako wstęp do późniejszych badań nad przedmiotami idealnymi.

Omówienie głównych rysów działalności naukowej Kazimierza Twardowskiego na katedrze uniwersyteckiej we Lwowie i doniosłego jego wpływu na rozwój tzw. szkoły lwowskiej, a pośrednio na stan współczesnej filozofii polskiej, stanowiły treść drugiej części przemówienia. Mówca zaznaczył przy tym, że rozmowa „O czynnościach i wytworach" jest próbą przezwyciężenia psychologizmu bez przyjmowania istnienia przedmiotów idealnych. Na zakończenie nawiązał mówca do pierwszego wykładu Prof. Twardowskiego na Uniwersytecie Lwowskim W r. 1894 poświęconego możliwości metafizyki i stwierdzającego, że filozofia może być uprawiana w sposób ściśle naukowy. (Autoreferat).

Prof. St. Łempicki, mówiąc o działalności Kazimierza Twardowskiego w Uniwersytecie i w społeczeństwie, wyróżnił w niej trzy okresy: 
przedwojenny, działalność w czasie wielkiej wojny i działalność w Polsce niepodległej. W pierwszym z tych okresów, który jest okresem najintensywniejszej pracy Twardowskiego, odgrywa on pierwszorzędną rolę we wszystkich dziedzinach życia uniwersyteckiego, by wymienić tylko reorganizację Powszechnych Wykładów Uniwersyteckich, kancelarii i biurowości uniwersyteckiej, referaty: wyższych studiów kobiecych, dostępu uczniów zagranicznych (m.in. z Królestwa!) do uniwersytetów w b. Galicji, a nade wszystko Jego rolę jako obrońcę polskości i autonomii Uniwersytetu. Równocześnie współdziała w założeniu I. ośmioklasowego gimnazjum żeńskiego w kraju, rozwija niestrudzoną działalność prelegenta i wykładowcy w ramach różnych zrzeszeń i instytucji we Lwowie i w całej Polsce, organizuje Zjazdy naukowe. Koroną tej działalności społecznej staje się bogata $\mathrm{w}$ rezultaty praca kierownicza w TNSW, której pomnikiem jest „Księga pamiątkowa” wydana przez to Towarzystwo ku uczczeniu zasług Twardowskiego, a zawierająca „Mowy i rozprawy" z okresu Jego prezesury. Zarysowuje się w nich całokształt oryginalnej pedagogiki, o silnym charakterze narodowym. Znawstwo w tej dziedzinie jako też w zakresie spraw organizacyjnych szkolnictwa predestynowało Twardowskiego do zajęcia wysokich stanowisk w szkolnictwie, od których objęcia jednak się uchylał, nie chcąc sprzeniewierzyć się nauce.

W czasie wojny światowej Twardowski jako „wojenny Rektor” na terenie emigracji wiedeńskiej zakłada „Dom Akademicki dla słuchaczów szkół najwyższych z Galicji i Bukowiny" i podejmuje akcję zapomogową i filantropijną dla młodzieży akademickiej. Dalsze dwa lata Rektoratu, 1915-1917, spędzone już we Lwowie w ciężkich i skomplikowanych warunkach wojennych, które uwypuklają hart, duch i takt wielkiego Rektora, poświęcone były obronie powagi i polskości Uniwersytetu oraz dbałości o dolę młodzieży.

W wolnej Polsce Twardowski wycofał się z rozlicznych zajęć społecznych do pracy naukowej i nauczycielskiej w Uniwersytecie, jako profesor, Przewodniczący Komisji Egzaminacyjnej, znawca problemów uniwersyteckich, uczestnik prac około budowy szkolnictwa polskiego. Testament swój, jako nauczyciel akademicki, zamknął w przepięknym, pożegnalnym niemal przemówieniu „O dostojeństwie Uniwersytetu”.

Omówiwszy - częściowo na podstawie pamiętnika Twardowskiego - Jego stosunek do jednostek bliższych i dalszych, scharakteryzował go mówca jako człowieka pełnego, któremu nic ludzkiego nie było obce, u którego rozum, uczucie i wola w idealnej niemal pozostawały harmonii i zakończył słowami: „W pamięci społeczeństwa polskiego zostanie Twardowski jako obywatel i działacz, który w przedświtowych i porannych godzinach nowej Polski budował mocno i solidnie, nie oszczędzając nigdy samego siebie, zręby narodowej kultury i - jak Sokrates - rzeźbił duszę polskiego człowieka". 
Polskie Towarzystwo Filozoficzne we Lwowie uczciło nadto pamięć swego Wielkiego Założyciela, Przewodniczącego i Członka Honorowego posiedzeniem naukowym, poświęconym Jego pamięci, $\mathrm{w}$ dniu 5 marca 1938. Na posiedzeniu tym dr L. Blaustein wygłosił odczyt pt. „Rola Kazimierza Twardowskiego w filozofii niemieckiej na przełomie XIX i XX wieku". (Autoreferat zob. poniżej w dziale Wykłady, Odczyty, Referaty).

\section{W Wilnie}

W Wileńskim Towarzystwie Filozoficznym odbyło się dnia 25 lutego 1938 posiedzenie naukowe, poświęcone pamięci Kazimierza Twardowskiego.

Na posiedzeniu tym prof. dr T. Czeżowski wygłosił odczyt pt. „Kazimierz Twardowski, (1866-1938)".

Biblioteka Uniwersytecka w Wilnie (dyr. dr A. Łysakowski) urządziła w czasie od 1 do 12 marca 1938 ku uczczeniu pamięci Kazimierza Twardowskiego pokaz Jego prac. W trzech gablotkach, umieszczonych w hallu na I p. zgrupowano dokoła fotografij Zmarłego, ukazujących Go też w gronie członków kółka filozoficznego oraz członków I Polskiego Zjazdu Filozoficznego, egzemplarze Jego książek i rozpraw, artykułów i przemówień, przekładów, których dokonał i które przejrzał, wydawnictw i czasopism, które obejmowała Jego działalność redakcyjna, dokumentów, ilustrujących Jego działalność organizacyjną w Polskim Towarzystwie Filozoficznym i na Uniwersytecie oraz jego stosunek do uczniów. Nie brakło też prac i artykułów o Kazimierzu Twardowskim, ksiąg pamiątkowych ku Jego czci wydanych, medalu na Jego cześć wybitego, wreszcie szeregu wspomnień pośmiertnych.

\section{W Łodzi}

W Towarzystwie Filozoficznym Societas Spinozana Polonica w Łodzi odbyła się dnia 7 kwietnia 1938 uroczysta akademia żałobna ku czci Kazimierza Twardowskiego.

Akademię zagaił dr N. Łubnicki, prezes Towarzystwa, podkreślając znaczenie naukowej, wychowawczej i organizacyjnej działalności Twardowskiego dla kultury polskiej i wpływ myśli Jego na prądy umysłowe w kraju i za granicą.

Następnie mgr H. Rundstein zarysował „Sylwetkę filozoficzną Kazimierza Twardowskiego”. Zaliczywszy Twardowskiego do „minimalistów" o wielkim poczuciu odpowiedzialności wewnętrznej, mówca zwrócił uwagę na niebywałą precyzję myśli i słowa wielkiego Nauczy- 
ciela i na ukutą przez Niego wiekopomną metodę rozstrzygania spornych, mętnie skreślonych zagadnień na drodze analizy semantyczno-logicznej (przykłady: odparcie relatywizmu epistemologicznego $\mathrm{w}$ walce o prawdy bezwzględne; odróżnienie kwestii uzasadnienia od kwestii genezy w kontrowersji „,aprioryzm - empiryzm”). - W „bezsystemowej” filozofii Twardowskiego mówca widzi zarys programu, który może uda się wykryć w całości przyszłym pokoleniom myślicieli.

$\mathrm{O}$ „Twardowskim jako etyku” mówił dr N. Łubnicki. Wskazał on na monolityczną budowę osobowości Twardowskiego i na zadziwiającą harmonię wiążącą Jego poglądy teoretyczne z działalnością praktyczną. Dalej zajął się mówca przedstawieniem poglądów etycznych Twardowskiego, wyprowadzając je z zasadniczych rysów charakterologicznych: jasnej i trzeźwej myśli, bezprzykładnej dyscypliny wewnętrznej, niepospolitego poczucia obowiązku i głębokiej, choć nie wyznaniowej religijności, każącej nie ustawać w poszukiwaniu Prawdy Bezwzględnej. Uczestnikom Akademii uprzytomniona została sokratyczna walka Twardowskiego z relatywizmem etycznym wyrosłym na gruncie epistemologicznym (subiektywizm) lub biologicznym (ewolucjonizm), oraz walka $\mathrm{z}$ hedonizmem psychologicznym, przywracająca godność i czystość czynowi ofiarnemu. W końcu przedstawiony został program drogiej sercu Twardowskiego „etyki naukowej” przeciwstawianej przez Niego etyce metafizycznej.

W przemówieniu pt. "Stanowisko Twardowskiego wobec pewnych zagadnień psychologicznych" wygłoszonym przez mgr M. Rajsfeldową przedstawione zostały poglądy Twardowskiego: na stosunek psychologii do dziedzin granicznych, filozofii i fizjologii; na rolę introspekcji i eksperymentu w psychologii; na klasyfikację zjawisk psychicznych ( $w$ związku z idiogenetyczną teorią sądu) oraz na istotę pojęć. Na zakończenie mówczyni uwydatniła znaczenie Twardowskiego jako strażnika naukowości psychologii i jej pierwszego oryginalnego teoretyka $\mathrm{w}$ Polsce.

O „Twardowskim jako pedagogu i organizatorze” mówiła R. Brodzka. Wykazując, że Twardowski z typu umysłowości był nauczycielem i wychowawca, mówczyni zanalizowała pod tym kątem widzenia oddziaływanie całej Jego twórczości na uczniów bliższych i dalszych, zwłaszcza zaś akcentowała wpływ Jego przez żywe słowo i porywający przykład osobisty. Dalej omówiona została wysoce cenna działalność Twardowskiego w szkolnictwie wyższym i średnim oraz praca naukowa i organizacyjna podjęta w celu krzewienia kultury filozoficznej (podręczniki i przekłady; pracownie, konwersatoria, zjazdy).

Dr N. Goldblum wygłosił przemówienie pt. „Rytm dziejowy myśli ludzkiej w ujęciu Twardowskiego". Mówca wskazał na niebywałą przejrzystość i spójność powiązań w wykładzie historycznym Twardowskiego. Wyraźność linii przewodnich kusi do uogólnień. To też mówca 
usiłował prześledzić historiozoficzne poglądy Twardowskiego, stosując do Jego prac historycznych brentanowską teorię czterofazowości myśli filozoficznej.

Akademię zamknęło pełne głębokiej czci „Wspomnienie o Profesorze" mgr. S. Koernera, obrazujące Twardowskiego jako Nauczyciela i Człowieka.

dr Halina Kowalska

\section{W Warszawie}

Prof. dr Wł. Witwicki wygłosił dnia 12 lutego 1938 w Radio warszawskim wspomnienie pozgonne o Kazimierzu Twardowskim, transmitowane przez wszystkie rozgłośnie polskie. Wspomnienie to ukazało się drukiem $\mathrm{w}$ formie nieco zmienionej $\mathrm{w}$ Polskim Archiwum Psychologii, X (1937/38), str. 31-32.

W ramach Konwersatorium Psychologicznego, prowadzonego przez prof. dr. Wł. Witwickiego, wygłosił dr W. Auerbach dnia 4 marca 1938 odczyt pt. „Rozwój filozoficzny Kazimierza Twardowskiego z szczególnym uwzględnieniem poglądów zawartych w rozprawie "Zur Lehre vom Inhalt und Gegenstand der Vorstellungen»".

W Warszawskim Towarzystwie Filozoficznym odbyło się dnia 9 maja 1938 posiedzenie naukowe poświęcone wspomnieniom o Kazimierzu Twardowskim.

Wobec licznie zebranego audytorium szereg mówców z grona uczniów Kazimierza Twardowskiego, a obecnie profesorów Uniwersytetu Józefa Piłsudskiego w Warszawie, mówiło na podstawie osobistych swych wspomnień o osobie Twardowskiego i Jego zasługach. Przemawiali: prof. dr Jan Łukasiewicz, prof. dr Stefan Baley, prof. dr Władysław Tatarkiewicz i prof. dr Tadeusz Kotarbiński. Prof. Łukasiewicz charakteryzował Zmarłego jako nauczyciela na tle wspomnień o Jego pracy w Kółku Filozoficznym Czytelni Akademickiej we Lwowie w ostatnich latach XIX wieku. - Prof. Baley mówił o Twardowskim jako o psychologu i przedstawiał Jego poglądy na metodę badań tej nauki oraz charakteryzował zasługi, które położył Twardowski dla naukowego uprawiania psychologii w Polsce. - Prof. Tatarkiewicz wspomniał na wstępie wielką uprzejmość, która cechowała Kazimierza Twardowskiego w stosunku z ludźmi, dalszą zaś część przemówienia (ogłoszoną drukiem w Przeglądzie Pedagogicznym LVII. 14) poświęcił omówieniu działalności i zasług Zmarłego na stanowisku prezesa Towarzystwa Nauczycieli Szkół Wyższych. - W końcu prof. Kotarbiński podał szereg wspomnień osobistych o Twardowskim, w których uwydatnił niektóre Jego cechy jako wychowawcy, Jego zasługi w obronie praw Uniwersytetu Lwowskiego podczas wielkiej wojny oraz pewne rysy znamienne Jego filozofii życia. 


\section{$* * *$}

\section{Nota Wydziału Polskiego Towarzystwa Filozoficznego}

Na posiedzeniu żałobnym odbytym dnia 12 lutego 1938 Wydział Polskiego Towarzystwa Filozoficznego postanowił m.in.: zająć się wydaniem spuścizny rękopiśmiennej Kazimierza Twardowskiego oraz przedstawić najbliższemu Walnemu Zgromadzeniu członków wniosek nadania Towarzystwu nazwy: „Polskie Towarzystwo Filozoficzne imienia Kazimierza Twardowskiego".

Dnia 5 marca 1938 zawiązał się w łonie Towarzystwa Komitet wydawniczy spuścizny rękopiśmiennej Kazimierza Twardowskiego. Prace tego Komitetu są w toku.

Tegoż dnia Doroczne Walne Zgromadzenie członków Towarzystwa uchwaliło jednomyślnie wniosek Wydziału w sprawie zmiany nazwy Towarzystwa. Uchwała ta wymaga zmiany statutu, o której zatwierdzenie Wydział czyni starania.

WYDZIAŁ POLSKIEGO TOWARZYSTWA FILOZOFICZNEGO zwraca się do czytelników "Ruchu Filozoficznego” z prośbą, by na podstawie swych wspomnień i listów mogących rzucić światło na myśl filozoficzną działalność pedagogiczną i osobę Kazimierza Twardowskiego dostarczyli materiałów, które by umożliwiły opracowanie dokładnej Jego biografii. 